\title{
Assessing the impact of excise duties on a state's revenues: the case of Greece
}

CHRISTOS PAPAGEORGIOU, Ph.D."

PANAGIOTIS FARLEKAS, Ph.D."

ZACHARIAS DERMATIS, Ph.D.*

ATHANASIOS ANASTASIOU, Ph.D."

PANAGIOTIS LIARGOVAS, Ph.D.*

Preliminary communication ${ }^{* *}$

JEL: H26, H70, H50

https://doi.org/10.3326/pse.45.3.4

\footnotetext{
* The authors would like to thank the two independent reviewers for their most useful suggestions and comments.

${ }^{* *}$ Received: April 17, 2021

Accepted: June 26, 2021

Christos PAPAGEORGIOU

Department of Economics, University of Peloponnese, Tripolis Campus, Tripolis, Greece

e-mail: papagechrp@gmail.com

ORCiD: 0000-0002-2674-5495

Panagiotis FARLEKAS

Department of Economics, University of Peloponnese, Tripolis Campus, Tripolis, Greece

e-mail: pfarlek@otenet.gr

ORCiD: 0000-0002-0414-4947

Zacharias DERMATIS

Department of Management Science and Technology, University of Peloponnese, Tripolis Campus, Tripolis, Greece

e-mail: zderm@uop.gr

ORCiD: 0000-0001-5605-3169

Athanasios ANASTASIOU

Department of Management Science and Technology, University of Peloponnese, Tripolis Campus, Tripolis, Greece

e-mail: athanastas@uop.gr

ORCiD: 0000-0003-4546-7846

Panagiotis LIARGOVAS

Department of Economics, University of Peloponnese, Tripolis Campus, Tripolis, Greece

e-mail: liargova@uop.gr

ORCiD: 0000-0002-2570-0156
} 


\section{Abstract}

The purpose of this study is to assess the impact of excise duties on tobacco products on state's revenues. Increasing excise duties on tobacco may act as a means to reduce the consumption of this product and thus to have a positive effect on citizens' health and prosperity. Our research showed that an increase in consumer income will result in a certain increase in cigarette consumption and an analogous decrease in fine-cut tobacco consumption, while a similar increase in cigarette price results in a small decrease in cigarette consumption and a very large increase in fine-cut tobacco consumption. Additionally, stepping up an anti-smoking campaign results in a decrease in cigarette consumption. Specifically for Greece we found that during 2019 and 2020 there will be a decrease in the state's revenues from excise duties on tobacco products of $€ 150-€ 200$ million each year.

Keywords: excise duties, specific excise tax, ad valorem excise tax, tobacco product, cigarette, fine-cut tobacco, Greece

\section{INTRODUCTION}

The main objectives of implementing excise duties are the following: (i) to increase state revenues, (ii) to restore external costs associated with the consumption of certain goods, (iii) to discourage the consumption of specific products and/or (iv) to achieve other objectives, such as improving resource allocation (Cnossen, 2000).

Determining the best method by which to levy excise duties is essential because they burden the final price of products and services and therefore drastically impact demand. Imposing a fixed excise duty per quantity of a product, i.e. specific excise duty, a fixed rate on the product's price, i.e. ad valorem excise duty or a combination thereof is a matter of careful choice, as the imposition of a fixed amount per quantity reduces the relative price difference between low- and highpriced products of different brands, while the imposition of a fixed rate on the original price increases the absolute price difference (Cnossen, 2000; Anastasiou et al., 2021a; Anastasiou et al., 2021b).

The choice between these two methods depends on whether the primary objective of a tax policy is to discourage consumption or increase state revenue, although a desire to improve product quality may also be of particular importance. Generally, since the damage caused by smoking is independent of prices, it is clear that excise duties must be set according to a certain quantity of the product or harmful substance. Thus, the excise duty on tobacco products should be based on the weight of tobacco, the number of cigarettes and their nicotine or tar content.

The harmonisation of taxes in the market for these products from countries imposing low excise duties restores balance to single-market systems in which free and undistorted competition plays a leading role (Cnossen, 2005; Komninos et al., 2020a; 2020b). However, the harmonisation of the tax system in the EU, despite having progressed to a certain extent, has not yet reached the point of remedying 
all the disturbances that exist or may arise from the imposition of excise duties on certain products in EU member states'.

Recently, research concerning excise revenues from tobacco products has been concentrated on obtaining formulas to calculate tobacco products' consumption - and thus to calculate state revenues - using mainly elasticities of process and income, without taking into account the social context, including such factors as an antismoking campaign.

The most important gap in our knowledge comes from the absence of any extended examination of the effect of an antismoking campaign on the reduction of the percentage of people who smoke and thus the reduction in state revenues from excises, as compared to the reduction of government expenditures stemming from the decline in smoking-related health issues.

The purpose of this study is to assess the impact of excise duties on tobacco products on government revenues in the European Union (EU) and specifically in Greece, using excise duty revenue figures for the 2007-2018 period, provided mainly by the Greek Statistics Service (ELSTAT).

We hypothesize that the exact effect of changing excise taxation will depend on the elasticities of demand for cigarettes and fine-cut tobacco. We used actual data on the demand for cigarettes and fine-cut tobacco and we applied logarithmic models to estimate the demand elasticities of these products by performing a linear regression.

After the introduction, this paper consists of six parts in which there are discussions of: (i) excise duties on tobacco products in the EU, presenting the existing framework of tobacco excise duties in the EU, (ii) excise duties on tobacco products in Greece, presenting the existing framework of tobacco excise duties in Greece, (iii) excise duties on tobacco products and anti-smoking campaigns, presenting the effect of anti-smoking campaigns in the consumption of tobacco products, (iv) estimation of the demand's elasticities of tobacco products in order to estimate the impact on state revenues deriving from a change in the excise duty, (v) results of the regression analysis, providing the estimated elasticities by linear regression, (vi) conclusions.

\section{EXCISE DUTIES ON TOBACCO PRODUCTS IN THE EU}

For tobacco products in particular, the binding framework of tobacco excise duties - agreed upon and established in the EU and considered to be part of the acquis is a reference point for all member states (Cnossen and Smart, 2005).

Initially, the southern member states, with the support of France, tried to reduce the specific excise duty and increase the ad valorem excise duty as a form of protection because the southern member states' tobacco products were cheaper than higher-quality American blends imported by northern member states. Since an 
excise duty based on the specific excise duty, i.e. a fixed amount per product quantity tends to shrink the relative price difference between low and high cost brands while an excise duty based on the ad valorem excise duty, i.e. a fixed percentage of the original price causes the exact opposite effect, the latter type was more favourable for producers in southern Europe (Papageorgiou et al., 2018).

Directive 72/464/EEC, Directive 77/805/EEC, Directive 79/32/EEC and Directive 92/79/EEC set the share of the ad valorem excise duty in a mixed excise system.

According to Directive 2002/10/EC, article 1: "(1) each member state shall apply an overall minimum excise duty (specific duty plus ad valorem duty excluding $V A T$ ), the incidence of which shall be set at $57 \%$ of the retail selling price (inclusive of all taxes) and which shall not be less than EUR 60 per 1,000 cigarettes for cigarettes of the price category most in demand. As of 1 July 2006, the figure of 'EUR 60' shall be replaced by 'EUR 64'. (2) Member states that levy an overall minimum excise duty of at least EUR 95 per 1,000 cigarettes for cigarettes of the price category most in demand need not comply with the $57 \%$ minimum incidence requirement. From 1 July 2006 the figure of 'EUR 95' shall be replaced by 'EUR 101'. (3) The overall minimum excise duty on cigarettes shall be determined on the basis of cigarettes of the price category most in demand according to data established as at 1 January of each year."

Following Directive 2011/64/EU and Commission Implementing Decision 2011/480/EU, and according to articles 8(3) and (8(4): “(3) Until 31 December 2013, the specific component of the excise duty shall not be less than 5\% and shall not be more than $76.5 \%$ of the amount of the total tax burden resulting from the aggregation of the following: (a) specific excise duty; (b) the ad valorem excise duty and the value added tax (VAT) levied on the weighted average retail selling price. (4) From 1 January 2014, the specific component of the excise duty on cigarettes shall not be less than $7.5 \%$ and shall not be more than $76.5 \%$ of the amount of the total tax burden resulting from the aggregation of the following: (a) specific excise duty; (b) the ad valorem excise duty and the VAT levied on the weighted average retail selling price."

Also, according to article 10 of the same Directive 2011/64/EU: "(1) The overall excise duty (specific excise duty and ad valorem excise duty excluding VAT) on cigarettes shall represent at least $57 \%$ of the weighted average retail selling price (WAP) of cigarettes released for consumption. That excise duty shall not be less than EUR 64 per 1,000 cigarettes irrespective of the weighted average retail selling price. [...] (2) From 1 January 2014, the overall excise duty on cigarettes shall represent at least $60 \%$ of the weighted average retail selling price (WAP) of cigarettes released for consumption. That excise duty shall not be less than EUR 90 per 1,000 cigarettes irrespective of the weighted average retail selling price."

Obviously, the price category most in demand was replaced by the weighted average price (WAP). After the introduction of the WAP, the basis for calculating the 
minimum rates for the excise duty on cigarettes and fine-cut tobacco also changed. The WAP for cigarettes and fine-cut tobacco would now be calculated on the basis of the total value of all cigarettes/tobacco put up for consumption based on the retail price inclusive of all taxes, divided by the total amount of cigarettes/fine-cut tobacco put up for consumption based on data relating to all quantities of these products consumed in the previous calendar year. Figure A1 shows the total taxation percentage (i.e. excise + VAT) on the final price of cigarettes in the EU's 28 member states (European Commission, 2018).

Continuous increases in the excise duties on tobacco products precipitated an increase in their final price, which, in turn, increased illegal trafficking of genuine products. When two countries in the Schengen zone have significantly divergent tobacco prices, the cross-border transport of tobacco products usually goes from member states with low prices to those with high prices. This transfer may be lawful if a citizen of a member state crosses the border to buy up to the maximum allowable quantity of tobacco or illegal if a citizen crosses the border to buy more than the permitted quantity and transfer it to sell it in the higher pricing area at a lower price. This is essentially the illegal trafficking of genuine products (i.e. contraband or Tobacco Industry illicit, known also as TI illicit). This situation may cause problems for member states wishing to increase the excise duties on and therefore prices of tobacco products. Any increase in the price of tobacco products in countries bordering lower-priced areas can create substantial price differentiation and therefore neutralise any potential benefits owing to the subsequent development of illicit trade.

Tobacco smuggling also includes the following: (i) counterfeiting that duplicates well-known brands that are produced without the legitimate owners' permission with the intention of cheating consumers and avoiding the payment of duties and (ii) illicit whites, with legally manufactured cigarettes in one country but smuggled and sold to another without duty payment. This category represents a significant proportion of the illegal cigarettes circulating with a cost not exceeding one euro per package. Figure A2 illustrates the development of cigarette's smuggling in the EU (KPMG, 2012-2019).

\section{EXCISE DUTIES ON TOBACCO PRODUCTS IN GREECE}

Cigarettes consumed within a country - whether produced within the country, produced and originating from another EU member state or imported from a third country - are subject to excise duty and VAT. Excise duty is structured by a fixed amount per 1,000 cigarettes, irrespective of their retail price, which was $€ 82.5$ per 1,000 cigarettes in 2018 , and by a fixed percentage of $26 \%$ of the current retail price of cigarettes (including taxes), which came to $€ 53.2428$ per 1,000 cigarettes in 2018. The retail sales price including taxes is the same as the WAP, which was $€ 204.78$ per 1,000 cigarettes in 2018 (Gov. Gazette 125B/2018). For cigarettes sold at a retail price lower than the WAP, a minimum excise duty of $75 \%$ of the total excise duty imposed on the cigarettes' WAP is set. Thus, the total excise duty 
is $€ 135.7428$ per 1,000 cigarettes, with a minimum excise duty of $€ 117.5$ per 1,000 cigarettes (based on Article 8(6) of Directive 2011/64/EU). Therefore, as of 2018 , the total excise duty was $66.29 \%$ of the cigarettes' WAP. For fine-cut tobacco, the excise duty, starting on 1 January 2017 , was $€ 170$ per kilogram (kg) net weight. In addition to the excise duty, the amount of $19.35 \%$ of the retail price of tobacco, all products were collected as VAT (Anastasiou et al., 2020).

Table 1 shows the changes in the minimum excise duty on cigarettes and fine-cut tobacco between 2007 and 2018 (Gov. Gazette 265A/2001; 169A/2006; Danchev et al., 2014; authors' calculations), according to the Article 8(6) of Directive 2011/64/EU; figure A3 shows the composition of the final price of tobacco products as a percentage of the original price, the excise duties and the VAT between 2007 and 2018 (Maniatis and Danchev, 2016). It is clear that total taxes (excise + VAT) account for approximately $86 \%$ of cigarettes' final price.

Furthermore, figure A4 depicts the evolution in the retail price of tobacco products. A significant factor in their increase is a corresponding increase in excise duties. The effects of these price changes are illustrated in the consumption histograms in figures A5 and A6 for cigarette and fine-cut tobacco consumption in the 2007-2018 period (Maniatis and Danchev, 2016; Maniatis, 2017; estimate for 2018). The revenue from excise duties on tobacco products is presented numerically in the diagram in figure A7 and as a percentage of gross domestic product (GDP) in figure A8 (ELSTAT, 2019).

The cigarette market exhibits a downward trend of almost 50\% over the 20072018 period (see figure A5). Simultaneously, there was an increase in the consumption of the substitute product, fine-cut tobacco, which doubled between 2007 and 2012 (see figure A6). However, a major increase in the excise duty on fine-cut tobacco in 2013 led to a significant reduction in its consumption.

The impact of the 2008 economic crisis - which is expressed as a decrease in GDP and Net National Disposable Income (NNDI) - followed by a rise in prices resulting from repeated excise duty increases can explain changes in the consumption of tobacco products and consumer habits to a large extent (see figure A9). The decline in the NNDI reduces consumers' purchasing power (income effect), leading to a decrease in the demand for cigarettes. A further price increase, mainly caused by an increase in excise duties, additionally reduces cigarette consumption. Thus, an increase in the consumption of lower-priced product substitutes, such as fine-cut tobacco, was observed (the substitution effect). The latter trend persisted until there was an increase in the excise duty on substitutes, as was the case for fine-cut tobacco. 


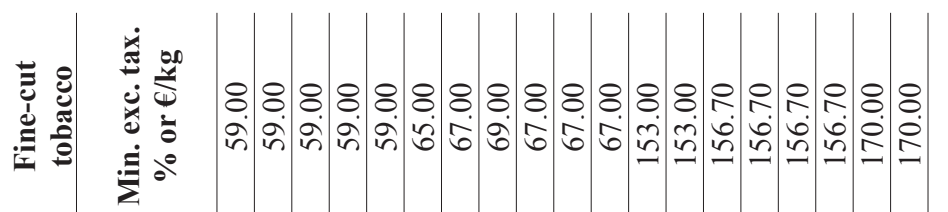

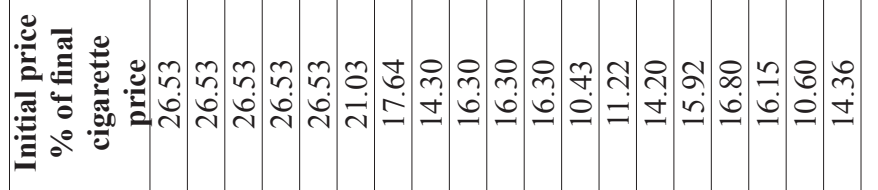

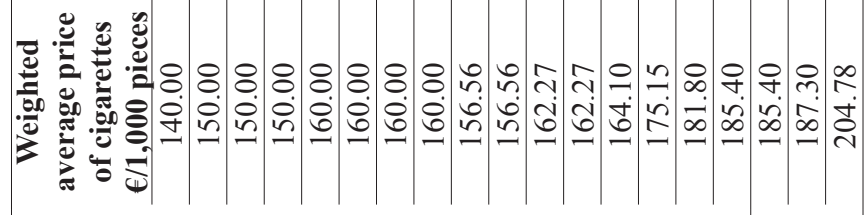

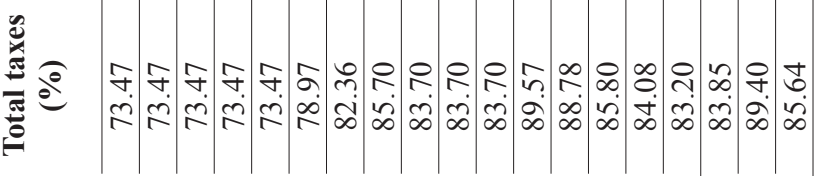
$\overline{0}$

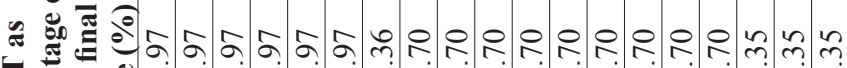

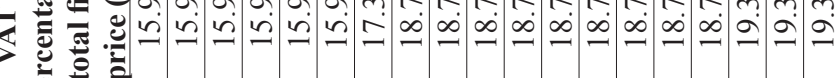
¿

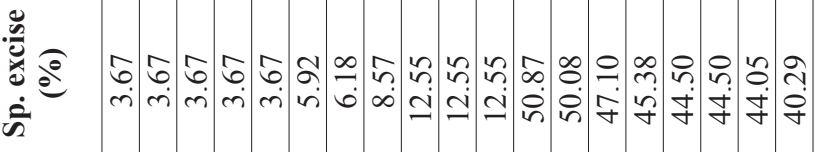

j"

造

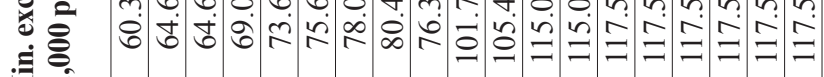

$\ddot{\infty}$

$\ddot{6}$

¿

छे

క

కี

కิ

ร

$\dot{\nabla}$

¿্

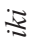

\$

§ 
As a direct consequence of increased excise duties on tobacco products, the consumption of smuggled cigarettes and other tobacco products has also increased. It is estimated that during 2018, Greece lost approximately $€ 670-€ 700$ million from the consumption of approximately 4 billion smuggled cigarettes (see figures A10 and A11). Significant figures for the illegal cigarette trade in the EU were given in an annual study conducted by KPMG on behalf of the Royal United Services Institute, which included quantitative data from KPMG's annual reports. According to the survey, in 2018, Greece ranked first among the EU member states with a high rate of $23.6 \%$ in the consumption of illegal cigarettes. In second place for the same was Ireland with $20.6 \%$, followed by Latvia with $19.5 \%$ and the United Kingdom with 19.3\% (KPMG, 2019).

\section{EXCISE DUTIES ON TOBACCO PRODUCTS AND ANTI-SMOKING CAMPAIGNS}

One main reason for a state to adopt higher excise duties on tobacco products is to increase the state's revenue. Another important reason is to burden smokers with the negative external costs that the state initially bears to protect public health from the deleterious effects of smoking. Perhaps the strongest argument for high tobacco excise duties is their effect of discouraging young people from taking up smoking (Warner, 1995).

Conversely, the reasons for mitigating the level of excise duties on tobacco products include consumer sovereignty, as imposing high taxes on fully informed individuals is a form of paternalism and internalising the external costs of smoking to protect public health causes severe social discrimination and regression. Additionally, the high level of excise duties on tobacco products engenders difficulties in controlling smuggling, which has reached alarming proportions, particularly in Europe (Cnossen and Smart, 2005).

The choice of the type of excise duty, between the fixed amount per unit of tobacco consumed and the fixed ad valorem percentage, is determined according to whether the primary objective of government policy is to discourage smokers or to increase revenue and whether an improvement in the quality of cigarettes is considered desirable. A fixed amount excise duty per quantity of product (specific rate), which tends to flatten price differentials, also tends to minimise cross-border purchases, particularly if excise duties have been harmonised between countries (ibid, 2005; Liargovas et al., 2019).

Determining the appropriate level and structure of excise duties is a complex issue. According to some economists, the application of the Pigou recipe for internalising external costs resulting from tobacco consumption cannot exceed certain limits. Moreover, negative attitudes towards paternalism and social discrimination have also been expressed (ibid, 2005).

Furthermore, excise duties cannot alone fulfil the objective of government policy - to "maximise social welfare" by eliminating smoking. Some believe that an 
information campaign may yield better results. For example, the results of the anti-smoking campaign in Greece are shown in figure A12, showing that the percentage of smokers in the population has decreased significantly over the last 10 years (ELSTAT, 2009, 2014; KAPA Research, 2012, 2017).

In addition, over-taxation has not proven to be an ideal practice, as shown by the increasing amount of tobacco product smuggling. In particular, during a period of economic crisis, when excise duties and other taxes increase, they negatively impact the development of the tobacco industry, with all corresponding consequences for growth and unemployment, while contributing to a rise in illegal trade, which ultimately affects state revenue negatively.

\section{ESTIMATION OF THE ELASTICITY OF TOBACCO PRODUCTS}

To estimate the impact on the state's revenues from an increase in the excise duty on a particular commodity in a multiple market structure, the demand for a certain product $i$, i.e. $Q_{i}$, can be expressed as follows:

$$
Q_{i}=f\left(Y, P_{1}, P_{2}, P_{3}, \ldots, A_{1}, A_{2}, A_{3}, \ldots\right)
$$

where $Y=$ income; $P=$ main and substitute product prices and $A=$ specific product characteristics, social conditions, etc.

Let us assume that certain excise duties, $T_{i, j}$, are imposed on product $i$ during year $j$. Subsequently, the state's total revenue, $R_{i, j}$, from these excise duties in year $j$ can be calculated as follows:

$$
R_{i, j}=T_{i, j} Q_{i, j}
$$

For this study, it is useful to quantify the effects of income and price that enable us to predict the future of the cigarette and fine-cut tobacco markets in order to calculate the Greek government's excise revenue from these products. In this context, a model for the demand (dependent variable) for these products in Greece was created, focusing on the elasticity of demand for NNDI and product price (independent variables), as demand elasticity measures the response to changes in income and prices. Additionally, we focus on the elasticity of demand for a social factor (independent variable), which is the anti-smoking campaign.

Thus, product demand is as follows (Jenkins, Kuo and Shukla, 2000, see also equation 1):

$$
Q=f(Y, P, A \ldots)
$$

where $Q=$ demand for tobacco products; $Y=\mathrm{NNDI} P=$ tobacco product price and $A=$ social factor (anti-smoking campaign factor). 
Demand is estimated using logarithms, and the coefficients resulting from this logarithmic transformation of the initial variables yield the elasticities of income $(Y)$, price $(P)$ and the anti-smoking campaign $(A)$. Coefficients $a, b$ and $c$ are elasticities that demonstrate the effects of changes in the income, price and anti-smoking campaign factors, respectively. For the case of cigarettes (ibid, 2000),

$$
\ln \left(Q_{c}\right)=a \ln (Y)+b_{c} \ln \left(P_{c}\right)+c \ln (A)+\text { constant }
$$

where $Q_{c}=$ demand for cigarettes; $Y=$ Net National Income Available; $P_{c}=$ product (cigarettes) price; $a=$ income elasticity; $b_{c}=$ price elasticity of cigarettes and $c=$ social factor (anti-smoking campaign factor) elasticity.

In the case of a substitute, which fine-cut tobacco is for cigarettes, the price of the basic product (cigarettes) is considered and included in the equation, which significantly affects the demand for the substitute product (fine-cut tobacco) (ibid, 2000):

$$
\ln \left(Q_{f}\right)=a \ln (Y)+b_{c} \ln \left(P_{c}\right)+b_{f} \ln \left(P_{f}\right)+c \ln (A)+\text { constant }
$$

where $Q_{f}=$ demand for fine-cut tobacco; $Y=\mathrm{NNDI} ; P_{c}=$ basic product (cigarettes) price; $P_{f}=$ substitute product (fine-cut tobacco) price; $a=$ income elasticity; $b_{c}=$ price elasticity of the basic product (cigarettes); $b_{f}=$ price elasticity of the substitute product (fine-cut tobacco) and $c=$ social factor (anti-smoking campaign factor) elasticity.

Data for the linear regression represented by equations 4 and 5 comprise the dependent variables, namely, demand for (consumption of) cigarettes, $Q_{c}$, and fine-cut tobacco, $Q_{p}$ from the annual data available from the Greek Ministry of Finance (see figures A5 and A6), distributed according to the state's revenues from excise duties on tobacco products for each three-month period (see figure A8) and smoothed using the moving average method (see figures A13, A14, A15).

As independent variables, we used NNDI (Y), which is available every three months, and smoothed it using the moving average method (see figure A16), the price of cigarettes, $P_{c}$, the price of fine-cut tobacco, $P_{f}$ available as a time series (see figure A4) and the anti-smoking campaign factor calculated every three months using a polynomial equation to fit the available data (see figure A12, where $\mathrm{x}=1$ for $2007, \mathrm{x}=2$ for $2006, \ldots \mathrm{x}=12$ for 2018).

Statistical Product and Service Solutions software was used for the linear regression analysis. Data were analysed using a beta factor to understand the links between the dependent and independent variables. Factor $\mathrm{R}^{2}$ was used to explain the dependent variables in the regression analysis. Moreover, t-statistics were used to determine the importance of each dependent variable to the independent variable, and an F-test was conducted to check the importance of all the independent variables. The standard estimation error was applied to test the confidence level and multiple regression analysis. 
Although the revenue elasticity of income and the value derived from the regression analysis seem reasonable, linear regression should be considered since the 48 values for each variable, covering a length of a 12-year series of data, were not large enough, although they cover the period since the beginning of the Greek economic crisis.

\section{RESULTS OF THE REGRESSION ANALYSIS}

As table 2 shows, the basic information needed to calculate price elasticity consists of a time series for the quantity demanded, the price in the marketplace, income information and the percentage of non-smokers (in the form of a polynomial function shown in figure A12).

Using the 12-year period, 2007-2018, divided into 48 quarters, the regression outputs are shown in table 3.

The results obtained from the cigarette regression analysis (see table 3) provide an income elasticity of demand, $a=0.827$, price elasticity of demand (cigarettes), $b_{c}$ $=-0.657$, and a social factor (anti-smoking campaign) elasticity of demand, $\mathrm{c}=$ -1.701 .

The results obtained from the fine-cut tobacco regression analysis (see table 3 ) yield an income elasticity of demand $\mathrm{a}=-0.863$, price elasticity of demand for a substitute product (i.e. fine-cut tobacco) $b_{f}=-1.170$, price elasticity of demand for the basic product (i.e. cigarettes) $b_{c}=3.489$ and the social factor (i.e. the antismoking campaign) elasticity of demand $\mathrm{c}=-2.651$.

The results calculated for the demands for cigarettes and fine-cut tobacco, respectively, are illustrated in figures A17 and A18. The results obtained from the models utilised are compared to the actual demand for cigarettes and fine-cut tobacco for the 2007-2018 period. Additionally, the demands for cigarettes and fine-cut tobacco for the 2019-2020 period were calculated using equations 4 and 5, respectively. From the calculated quantities, we can ascertain the state's revenue from excise duties on tobacco products for 2019 and 2020.

From the results determined for prices and income elasticities, it is clear that cigarette smokers initially react to a cigarette price increase by consuming fine-cut tobacco. However, most return to cigarette consumption as soon as their income or the price of fine-cut tobacco increases. Generally, a 10\% increase in a consumer's income results in a corresponding $8.27 \%$ increase in cigarette consumption; a $10 \%$ cigarette price increase results in a $6.57 \%$ decrease in cigarette consumption. A $10 \%$ increase in a consumer's income results in a corresponding $8.63 \%$ decrease in finecut tobacco consumption, and a $10 \%$ cigarette price increase results in a $34.89 \%$ increase in fine-cut tobacco consumption, while a $10 \%$ fine-cut tobacco price increase results in an $11.70 \%$ decrease in fine-cut tobacco consumption. For both cases, a $10 \%$ increase in an anti-smoking campaign results in a $17.01 \%$ decrease in cigarette consumption and $26.51 \%$ decrease in fine-cut tobacco consumption. 
398

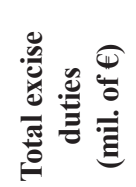

|

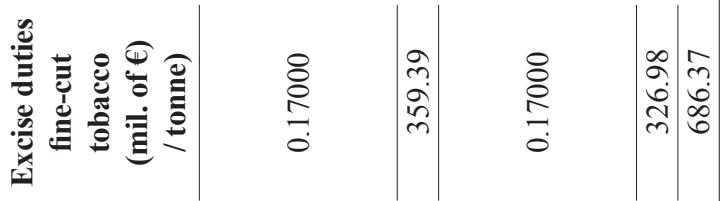

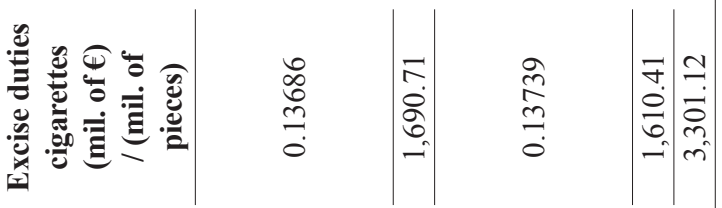

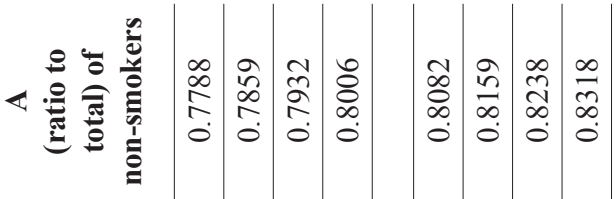

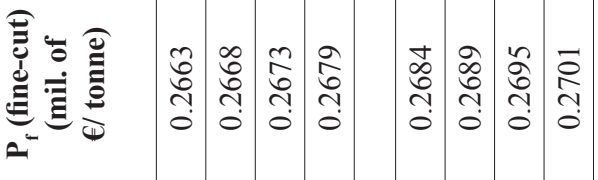

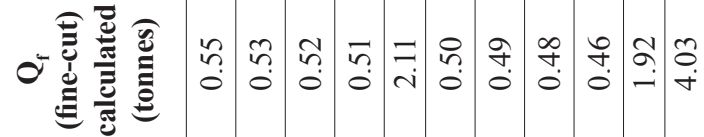
5

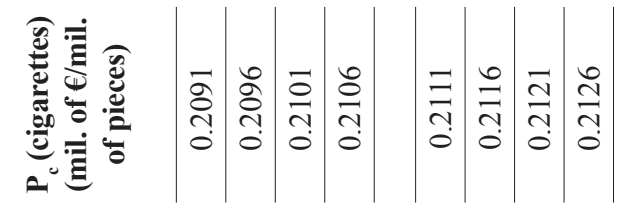

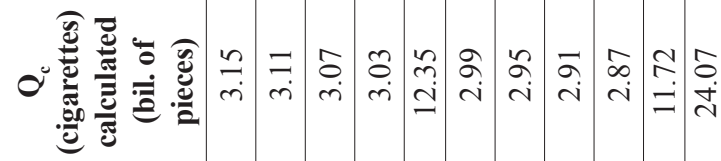

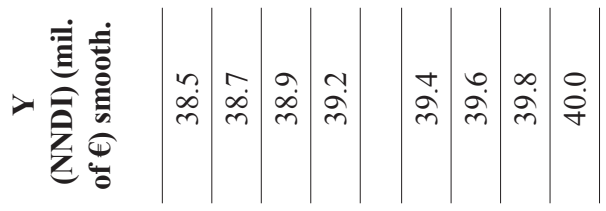

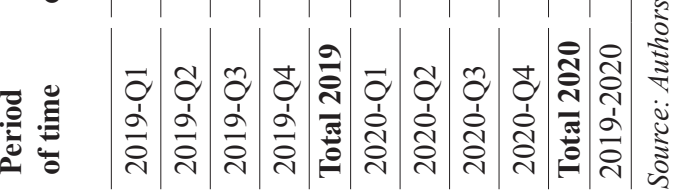


TABle 3

Linear regression data and results

\begin{tabular}{|c|c|c|c|c|c|c|}
\hline Per. of time & LnY & LnQc & LnPc & LnAc & LnQf & LnPf \\
\hline 2007-Q1 & 10.7299 & 2.0383 & -2.1037 & -0.4891 & -1.0966 & -2.1286 \\
\hline 2007-Q2 & 10.7354 & 2.0706 & -2.0956 & -0.4892 & -1.0643 & -2.1286 \\
\hline 2007-Q3 & 10.7524 & 2.0773 & -2.0875 & -0.4891 & -1.0577 & -2.1203 \\
\hline 2007-Q4 & 10.7649 & 2.0930 & -2.0794 & -0.4887 & -1.0419 & -2.1203 \\
\hline 2008-Q1 & 10.7786 & 2.0910 & -2.0794 & -0.4881 & -1.0006 & -2.1203 \\
\hline 2008-Q2 & 10.7880 & 2.0621 & -2.0636 & -0.4872 & -1.0294 & -2.1120 \\
\hline 2008-Q3 & 10.7982 & 2.0731 & -2.0479 & -0.4861 & -1.0184 & -2.1078 \\
\hline 2008-Q4 & 10.8104 & 2.0726 & -2.0402 & -0.4848 & -1.0190 & -2.1037 \\
\hline 2009-Q1 & 10.8086 & 2.0242 & -2.0326 & -0.4832 & -0.9205 & -2.0996 \\
\hline 2009-Q2 & 10.7973 & 2.0499 & -2.0025 & -0.4814 & -0.8948 & -2.0794 \\
\hline 2009-Q3 & 10.8061 & 2.0379 & -1.9841 & -0.4793 & -0.9068 & -2.0755 \\
\hline 2009-Q4 & 10.7906 & 2.0462 & -1.9805 & -0.4770 & -0.8985 & -2.0636 \\
\hline 2010-Q1 & 10.7862 & 1.8601 & -1.9805 & -0.4745 & -0.6879 & -2.0675 \\
\hline 2010-Q2 & 10.7883 & 1.9436 & -1.9733 & -0.4717 & -0.6045 & -2.0025 \\
\hline 2010-Q3 & 10.7726 & 1.9534 & -1.8326 & -0.4687 & -0.5946 & -1.9173 \\
\hline 2010-Q4 & 10.7531 & 1.9343 & -1.8643 & -0.4655 & -0.6138 & -1.8971 \\
\hline 2011-Q1 & 10.7254 & 1.8145 & -1.8643 & -0.4620 & -0.4187 & -1.8452 \\
\hline 2011-Q2 & 10.6953 & 1.7682 & -1.8579 & -0.4584 & -0.4649 & -1.8420 \\
\hline 2011-Q3 & 10.6714 & 1.7739 & -1.8326 & -0.4544 & -0.4593 & -1.8389 \\
\hline 2011-Q4 & 10.6481 & 1.8210 & -1.8202 & -0.4503 & -0.4122 & -1.8326 \\
\hline 2012-Q1 & 10.6141 & 1.6302 & -1.7838 & -0.4460 & -0.3242 & -1.8264 \\
\hline 2012-Q2 & 10.5954 & 1.6447 & -1.8018 & -0.4414 & -0.3097 & -1.8018 \\
\hline 2012-Q3 & 10.5803 & 1.6238 & -1.8452 & -0.4366 & -0.3305 & -1.7958 \\
\hline 2012-Q4 & 10.5700 & 1.5755 & -1.8140 & -0.4317 & -0.3788 & -1.7898 \\
\hline 2013-Q1 & 10.5623 & 1.5634 & -1.8079 & -0.4265 & -0.4422 & -1.7779 \\
\hline 2013-Q2 & 10.5487 & 1.4900 & -1.7603 & -0.4211 & -0.5156 & -1.6607 \\
\hline 2013-Q3 & 10.5322 & 1.4971 & -1.7487 & -0.4155 & -0.5085 & -1.5702 \\
\hline 2013-Q4 & 10.5270 & 1.5127 & -1.7430 & -0.4097 & -0.4929 & -1.5465 \\
\hline 2014-Q1 & 10.5105 & 1.4693 & -1.7204 & -0.4038 & -0.5091 & -1.5465 \\
\hline 2014-Q2 & 10.5100 & 1.4619 & -1.7148 & -0.3976 & -0.5166 & -1.5418 \\
\hline 2014-Q3 & 10.5101 & 1.4411 & -1.7093 & -0.3913 & -0.5374 & -1.5371 \\
\hline 2014-Q4 & 10.5114 & 1.4409 & -1.7037 & -0.3847 & -0.5376 & -1.5371 \\
\hline 2015-Q1 & 10.5133 & 1.4227 & -1.6983 & -0.3780 & -0.4873 & -1.5279 \\
\hline 2015-Q2 & 10.5095 & 1.4311 & -1.6928 & -0.3712 & -0.4789 & -1.5279 \\
\hline 2015-Q3 & 10.5057 & 1.4405 & -1.6874 & -0.3641 & -0.4695 & -1.5187 \\
\hline 2015-Q4 & 10.4989 & 1.4173 & -1.6820 & -0.3569 & -0.4927 & -1.5141 \\
\hline 2016-Q1 & 10.5036 & 1.3096 & -1.6766 & -0.3496 & -0.5519 & -1.4653 \\
\hline 2016-Q2 & 10.5059 & 1.3084 & -1.6713 & -0.3420 & -0.5532 & -1.4524 \\
\hline 2016-Q3 & 10.5099 & 1.4707 & -1.6660 & -0.3344 & -0.3908 & -1.4355 \\
\hline 2016-Q4 & 10.5084 & 1.3565 & -1.6607 & -0.3265 & -0.5050 & -1.4271 \\
\hline 2017-Q1 & 10.5025 & 1.3565 & -1.6348 & -0.3186 & -0.4521 & -1.3704 \\
\hline 2017-Q2 & 10.5104 & 1.2947 & -1.6145 & -0.3104 & -0.5140 & -1.3626 \\
\hline 2017-Q3 & 10.5171 & 1.0575 & -1.5995 & -0.3022 & -0.7512 & -1.3548 \\
\hline 2017-Q4 & 10.5297 & 1.1995 & -1.5896 & -0.2938 & -0.6092 & -1.3471 \\
\hline 2018-Q1 & 10.5365 & 1.0929 & -1.5857 & -0.2853 & -0.6052 & -1.3432 \\
\hline 2018-Q2 & 10.5405 & 1.1589 & -1.5852 & -0.2766 & -0.5391 & -1.3394 \\
\hline 2018-Q3 & 10.5450 & 1.1941 & -1.5765 & -0.2679 & -0.5040 & -1.3356 \\
\hline 2018-Q4 & 10.5523 & 1.1816 & -1.5702 & -0.2590 & -0.5164 & -1.3250 \\
\hline
\end{tabular}




\begin{tabular}{|c|c|c|c|c|c|c|}
\hline \multirow{2}{*}{\multicolumn{2}{|c|}{ Model }} & \multicolumn{2}{|c|}{ Unstandardized coefficients } & \multirow{2}{*}{$\frac{\text { Stand. coeffic. }}{\text { Beta }}$} & \multirow[b]{2}{*}{ t } & \multirow[b]{2}{*}{ Sig. } \\
\hline & & B & Std. error & & & \\
\hline \multirow{4}{*}{1} & (Constant) & -9.039 & 1.536 & & -5.885 & 0.000 \\
\hline & Ln_Y & 0.827 & 0.162 & 0.306 & 5.092 & 0.000 \\
\hline & Ln_Pc & -0.657 & 0.175 & -0.342 & -3.765 & 0.000 \\
\hline & Ln_A & -1.701 & 0.310 & -0.378 & -5.480 & 0.000 \\
\hline \multicolumn{7}{|c|}{ Coefficients } \\
\hline \multirow{2}{*}{\multicolumn{2}{|c|}{ Model }} & \multicolumn{2}{|c|}{ Unstandardized coefficients } & Stand. coeffic. & & \\
\hline & & $\mathbf{B}$ & Std. error & Beta & $\mathbf{t}$ & Sig. \\
\hline \multirow{5}{*}{2} & (Constant) & 11.758 & 4.083 & & 2.880 & 0.006 \\
\hline & Ln_Y & -0.863 & 0.397 & -0.445 & -2.175 & 0.035 \\
\hline & Ln_Pf & -1.170 & 0.485 & -1.443 & -2.414 & 0.020 \\
\hline & $\mathrm{Ln \_ Pc}$ & 3.489 & 0.479 & 2.522 & 7.284 & 0.000 \\
\hline & Ln_A & -2.651 & 0.824 & -0.819 & -3.217 & 0.002 \\
\hline
\end{tabular}

Source: Author's calculations.

From the results, we can estimate the state's revenues from excise duties in tobacco products, assuming growth to be $2.1 \%$ and $2.2 \%$ and inflation to be $0.8 \%$ and $0.8 \%$ for 2019 and 2020 , respectively.

Excise taxes for cigarettes will be $€ 0.13686 /$ piece for 2019 and $€ 0.13739$ /piece for 2020; excise taxes for fine-cut tobacco will be $€ 0.1700$ /gram for 2019 and $€ 0.1700$ $€ /$ gram for 2020. As shown in table 2, revenues from excise taxes of cigarettes for 2019 and 2020 will be $€ 3,301.12$ million for the two years combined, and revenues from excise taxes of fine-cut tobacco for 2019 and 2020 will be $€ 686.37$ million for both years. Thus, the total amount of excise taxes revenues is expected to be $€ 3,987.49$ million for both years.

The decreased quantities of cigarettes consumed during 2019 and 2020 are explained by the effect of the increase in NNDI being less significant than that of the anti-smoking campaign. The increased price of fine-cut tobacco, increase in NNDI (causing an increase in cigarette consumption and a decrease in fine-cut tobacco consumption) and the anti-smoking campaign are the primary reasons for the decrease in the consumed quantities of fine-cut tobacco. The final result is an overall decrease in the state's revenue from excise duties on tobacco products.

\section{CONCLUSION}

From the previous analysis, we can conclude that the exact effect of changing excise taxation depends on the elasticities of demand for cigarettes and fine-cut tobacco. We used actual data on the demand for cigarettes and fine-cut tobacco and applied logarithmic models to estimate the demand elasticities of these products by performing a linear regression. 
Generally, an increase in consumer income will result in a certain increase in cigarette consumption and an analogous decrease in fine-cut tobacco consumption, while a similar increase in cigarette price will result in a fairly small decrease in cigarette consumption and a very high increase in fine-cut tobacco consumption. Additionally, an increase in the effectiveness of the anti-smoking campaign results in a decrease in cigarette consumption and a significantly higher decrease in fine-cut tobacco consumption. Specifically for Greece we estimated a decrease in the state's revenues from excise duties on tobacco products by $€ 150-€ 200$ million for each year during 2019 and 2020.

Although the elasticities obtained by regression analysis seem reasonable, their outputs should be still considered to be approximations, although these results cover the time period from the beginning of the Greek economic crisis. It is that similar conditions in other European countries be studied with the inclusion of other social parameters affecting smoking habits.

\section{Disclosure statement}

The authors state that they do not have any financial or other substantive conflict of interest. 


\section{REFERENCES}

1. Anastasiou, A., Kalligosfyris, C., Kalamara, E., 2021a. An Analysis of the Efficiency of Tax Administrations of 26 European Countries in 2017. Bulletin for International Taxation, 25(2), pp. 67-83.

2. Anastasiou, A., Kalligosfyris, C. and Kalamara, E., 2021b. Determinants of tax evasion in Greece: Econometric analysis of co-integration and causality, variance decomposition and impulse response analysis. Bulletin of Applied Economics, 8(1), pp. 29-57.

3. Anastasiou, A., Kalamara, E. and Kalligosfyris, C., 2020. Estimation of the size of tax evasion in Greece. Bulletin of Applied Economics, 7(2), pp. 97-107.

4. Cnossen, S., 2000. Corporation Taxes in the New Eu Member States: A Survey And Evaluation. De Economist, 153(2), pp. 199-226.

5. Cnossen, S., 2005. Economics and Politics of Excise Taxation. In: S. Cnossen, ed. Theory and Practice of Excise Taxation - Smoking, Drinking, Gambling, Polluting, and Driving. Oxford University Press. https://doi.org/10.1093/ 0199278598.003.0001

6. Cnossen, S. and Smart, M., 2005. Taxation of Tobacco. In: S. Cnossen, ed. Theory and practice of excise taxation: smoking, drinking, gambling, polluting, and driving. Oxford: Oxford University Press. https://doi.org/10.17310/ ntj.2005.4.11

7. Danchev, S., Maniatis, G. and Touriki, C., 2014. Assessment of the current framework for the taxation of tobacco products in Greece. Athens: Foundation for Economic \& Industrial Research.

8. ELSTAT, 2009. Research for the reduction of smoking in Greece. Athens: ELSTAT.

9. ELSTAT, 2014. Research for the reduction of smoking in Greece. Athens: ELSTAT.

10. ELSTAT, 2019. Revenues / Code, before returns. Athens: ELSTAT.

11. European Commission, 2017. Taxation and Customs Union - Business Excise duties on alcohol, tobacco and energy - Excise Duties on Tobacco. https://doi.org/10.1017/cbo9781107109926.026

12. European Commission, 2018. Excise Duty Tables - Part III - Manufactured Tobacco. Directorate - General Taxation and Customs Union - Indirect Taxation and Tax administration - Indirect taxes other than VAT.

13. Komninos, D. et al., 2020a. The multiplicity and the frequent changes of the tax legislation in the Greek Tax Administration. Technium Social Sciences Journal, 13(1), pp. 395-407.

14. Komninos, D. et al., 2020b. The Effect of over-taxation and Corruption at Commercial Enterprises in Greece: Evidence from a Survey Experiment. Journal of Statistical and Econometric Methods, 9(4), pp. 153-170.

15. Liargovas, P. et al., 2019. The contribution of electronic tax transactions to increasing the productivity of Greek Tax Administration and serving services for citizens and businesses. China-USA Business Review, 18(1), pp. 12-21. 
16. Papageorgiou, C. et al., 2018. Corruption Perception Index (CPI), as an Index of Economic Growth for European Countries. Theoretical Economics Letters, 8(3), pp. 524-537.

17. Taxation and Customs Union - European Commission, 2021. Excise Duties on Tobacco - Taxation and Customs Union - European Commission.

18. Jenkins, G., Kuo, C. Y. and Shukla, G., 2000. Tax analysis and revenue forecasting - Issues and Techniques. Harvard: Harvard Institute for International Development.

19. KAPPA Research, 2012. Research for the reduction of smoking in Greece. Athens.

20. KAPPA Research, 2017. Research for the reduction of smoking in Greece. Athens.

21. KPMG - Project STAR, 2012. Report-2011 Results. London: KPMG.

22. KPMG - Project STAR, 2013. Report-2012 Results. London: KPMG.

23. KPMG - Project STELLA, 2019. A study of the illicit cigarette market in the European Union - 2018 Results.

24. KPMG - Project SUN, 2014. A study of the illicit cigarette market in the European Union, Norway and Switzerland - 2013 Results. London: KPMG.

25. KPMG - Project SUN, 2015. A study of the illicit cigarette market in the European Union, Norway and Switzerland - 2014 Results. London: KPMG.

26. KPMG - Project SUN, 2016. A study of the illicit cigarette market in the European Union, Norway and Switzerland - 2015 Results. London: KPMG.

27. KPMG - Project SUN, 2017. A study of the illicit cigarette market in the European Union, Norway and Switzerland - 2016 Results. London: KPMG.

28. KPMG - Project SUN, 2018. A study of the illicit cigarette market in the European Union, Norway and Switzerland - 2017 Results. London: KPMG.

29. Maniatis, G. and Danchev, S., 2016. Impact of the new tax increase on tobacco products. Athens: Foundation for Economic \& Industrial Research.

30. Maniatis, G., 2017. Economic impact of the increase in excise duties rates on tobacco and oil products. Presentation. Athens: Foundation for Economic \& Industrial Research.

31. Warner, K. E., 1995. Criteria for determining an optimal cigarette tax. Tobacco Control, (4), pp. 380-386. https://doi.org/10.1136/tc.4.4.380 


\section{Figure A1}

Total taxation (excise $+V A T)$ as a percentage of the final price of cigarettes in the EU (July 2018)

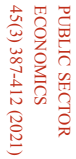

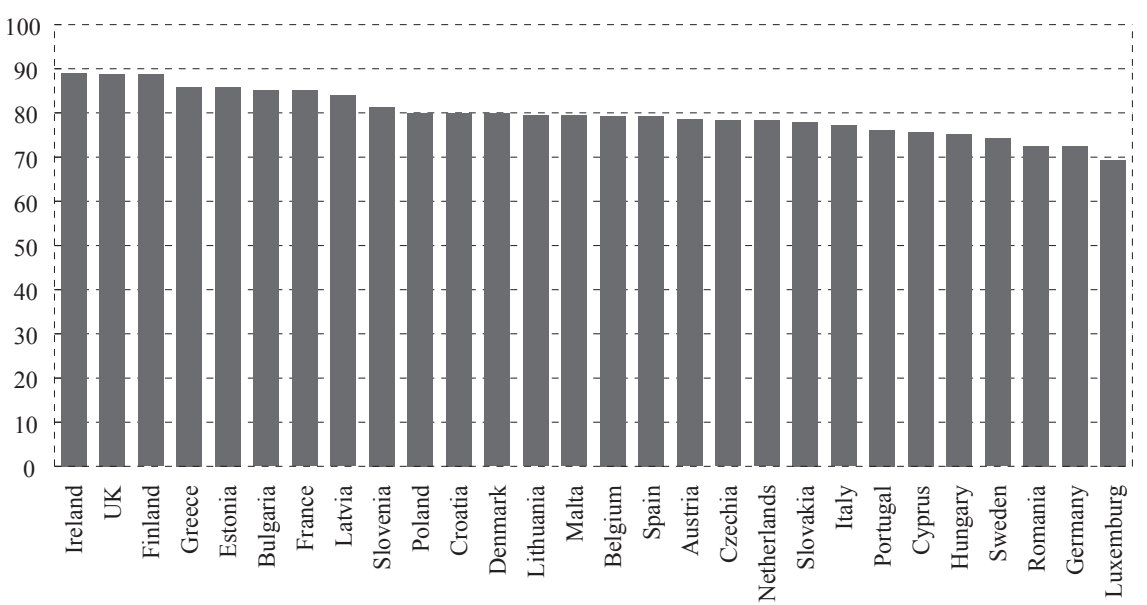

Source: European Commission (2018).

\section{Figure A2}

Quantity and types (in billions of pieces) of illegal cigarettes in the EU

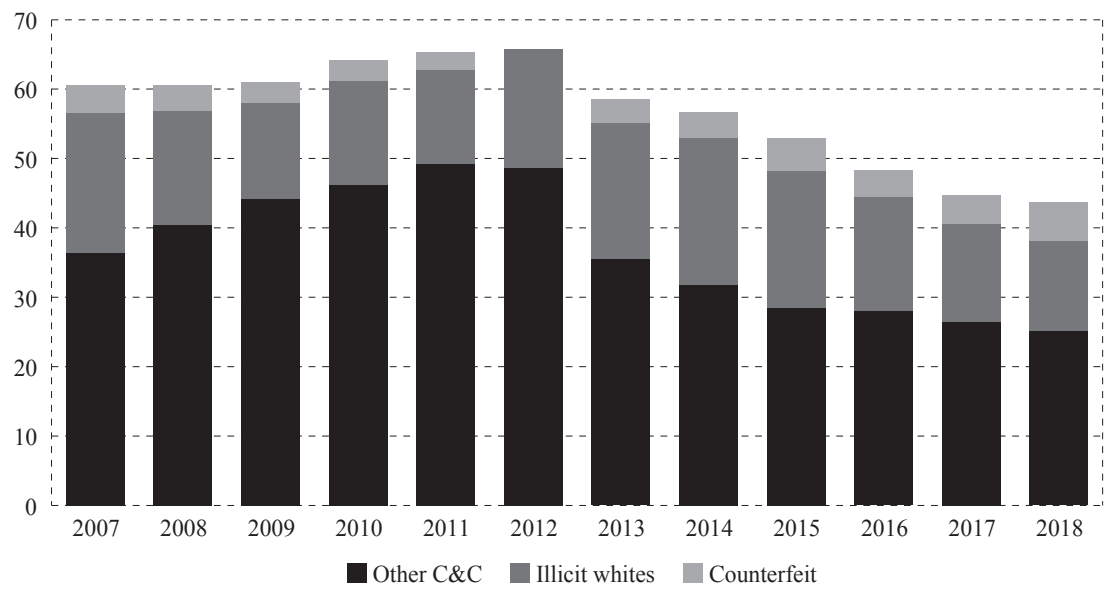

Source: KPMG (2012-2019). 
Figure A3

Composition (\%) of the final price of cigarettes in Greece (2007-2018)

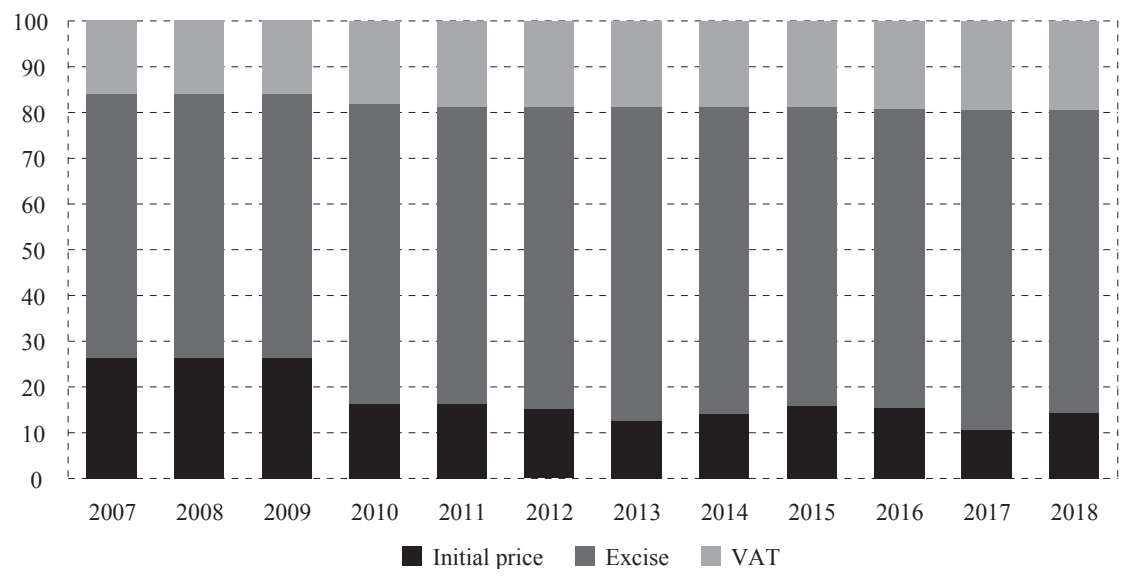

Source: Danchev et al. (2014); Maniatis and Danchev (2016); European Commission (2019).

\section{Figure A4}

Changes in the price of cigarettes and fine-cut tobacco (2007-2018)

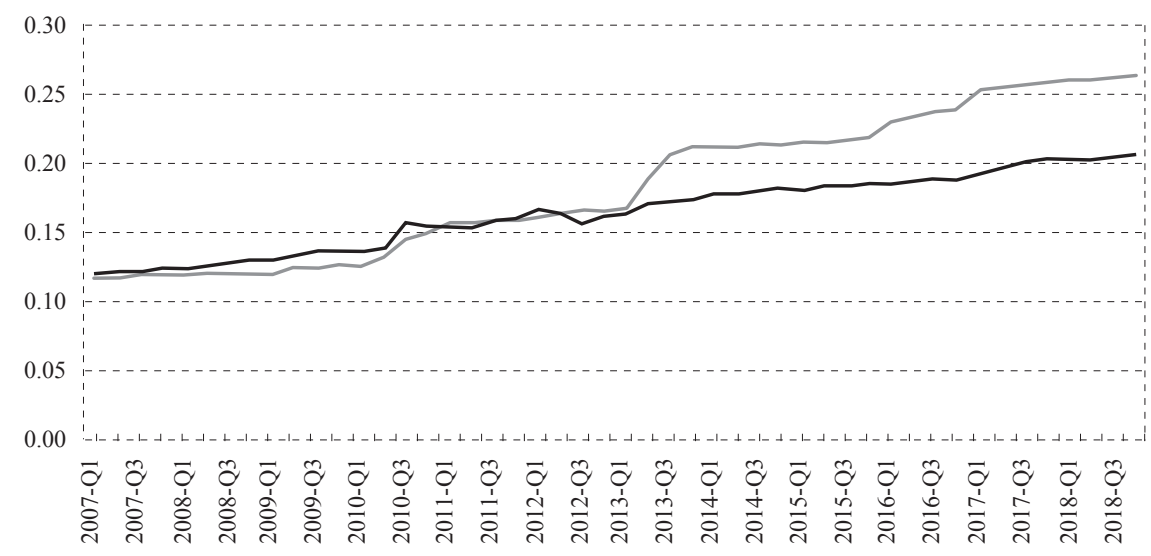

— P cigarettes (mil. €/mil. pieces) _ P fine-cut (mil. €/tonne)

Source: Danchev et al. (2014); Maniatis and Danchev (2016); KPMG (2012-2019). 


\section{Figure A5}

Total consumption of cigarettes (2007-2018) in billions of cigarettes
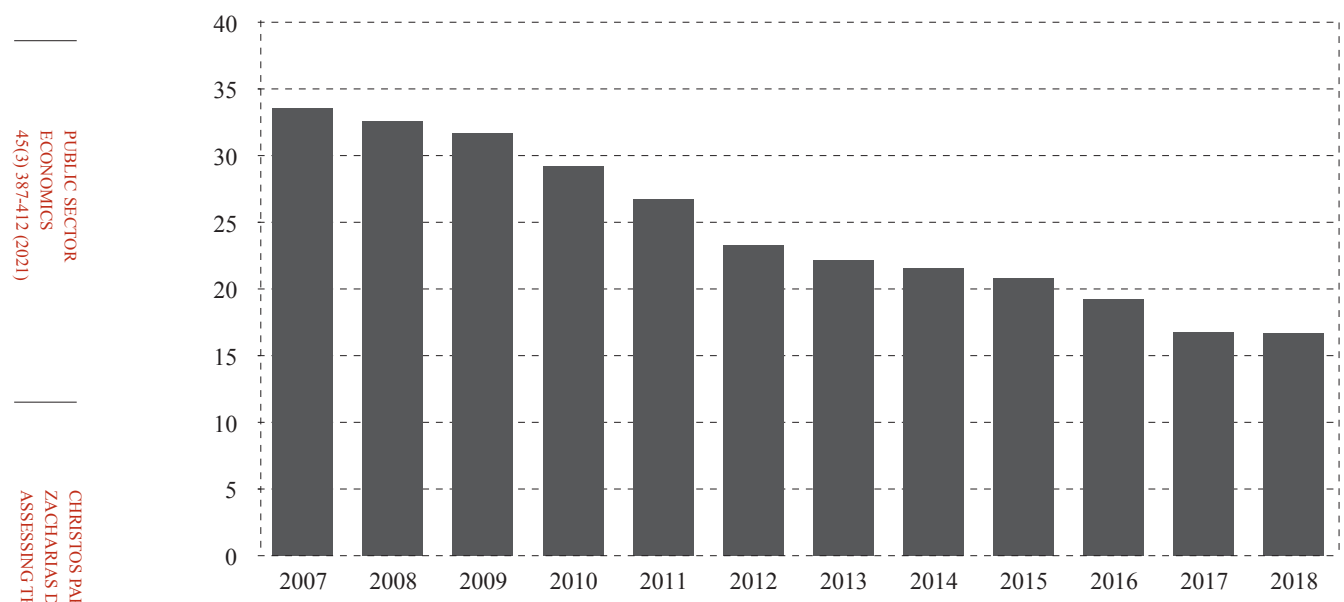

Source: Project Sun \& Star Reports and KPMG (2012-2019).

\section{Figure A6}

Total consumption of fine-cut tobacco (2007-2018) in thousands tonnes

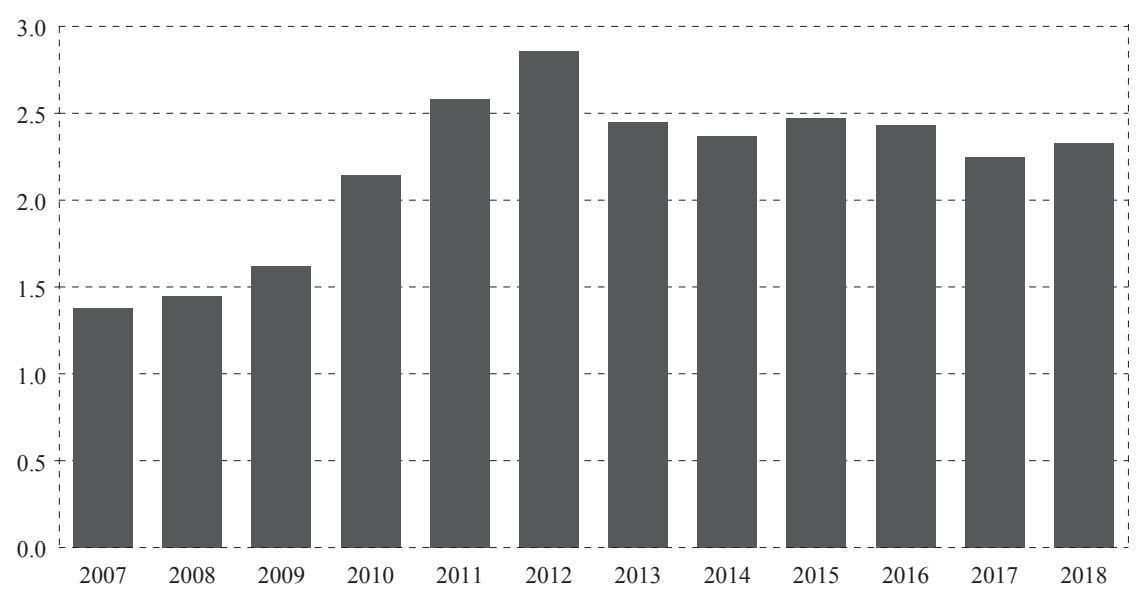

Source: Danchev et al. (2014); Maniatis and Danchev (2016). 
Figure A7

Revenue from the excise taxation of tobacco products in billions of euros

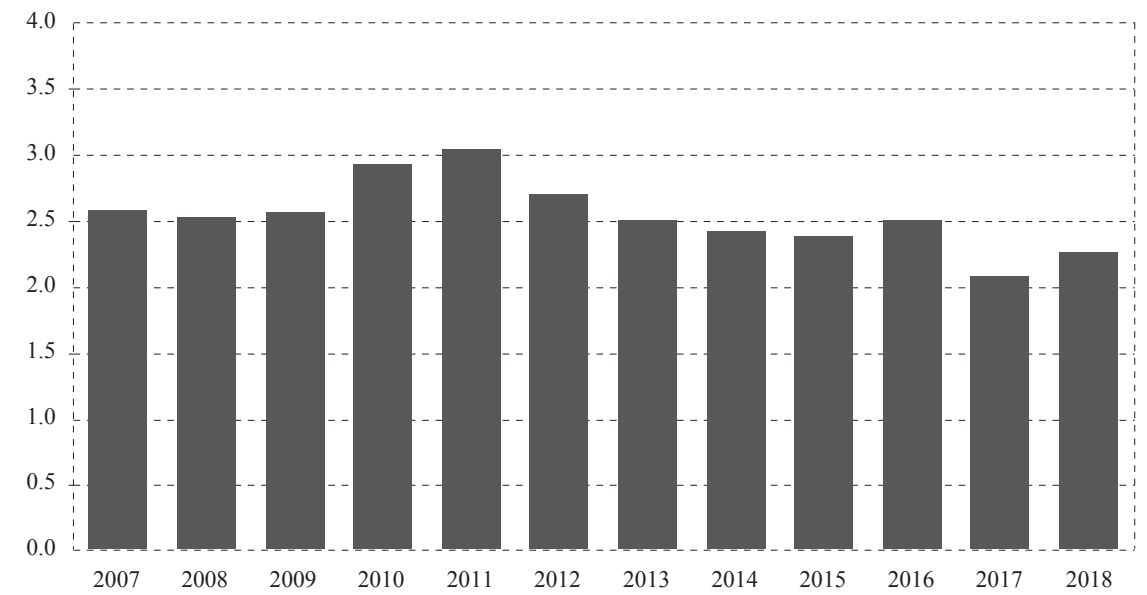

Source: ELSTAT (2019) and authors' calculations.

\section{Figure A8}

Revenue from the excise taxation of tobacco products as a percentage of GDP

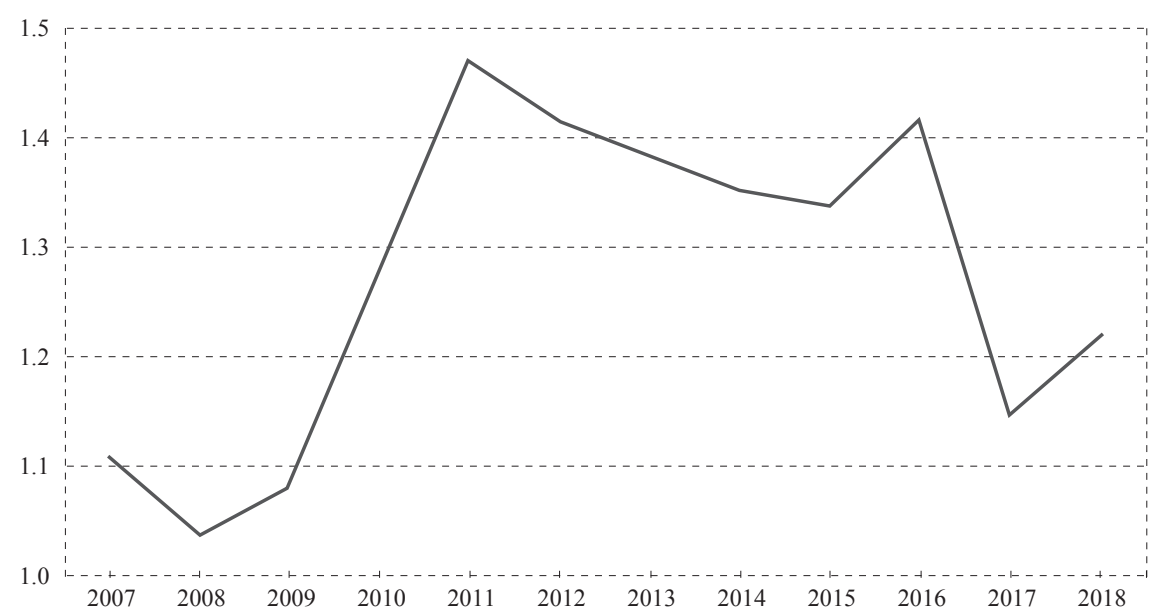

Source: ELSTAT (2019) and authors' calculations. 
Consumption of tobacco products (weight \%) before and after the beginning of the global economic crisis

2008

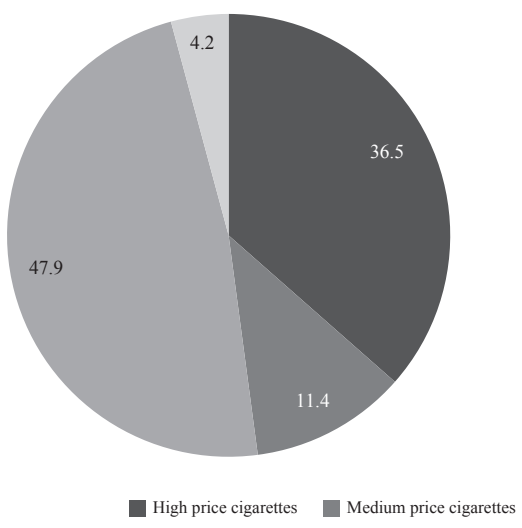

Source: Danchev et al. (2014).

\section{Figure A10}

Consumed counterfeit, illicit whites and other $C \& C$ cigarette consumption as a percentage of total tobacco consumption in Greece (2007-2018)

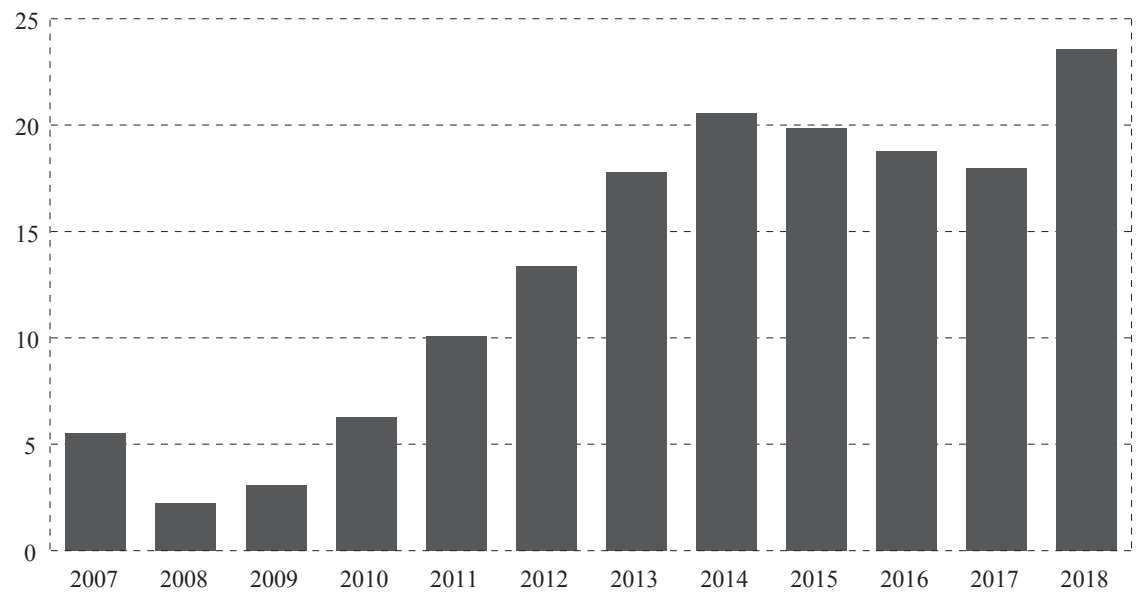

Source: KPMG (2012-2019).

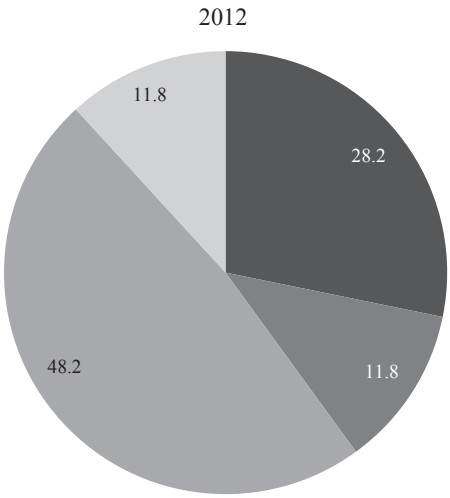

Fine cut tobacco 
Figure A11

Consumed counterfeit, illicit whites and other C\&C cigarette consumption in Greece in billions of cigarettes (2007-2018)

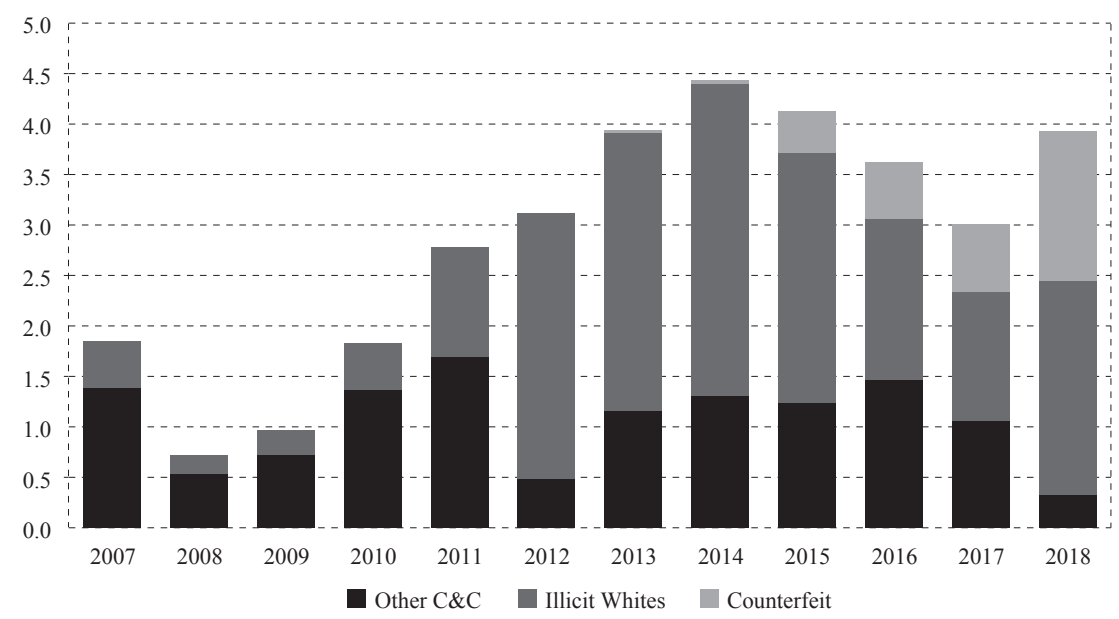

Source: KPMG (2012-2019).

\section{Figure A12}

Percentage of smokers in the population of Greece

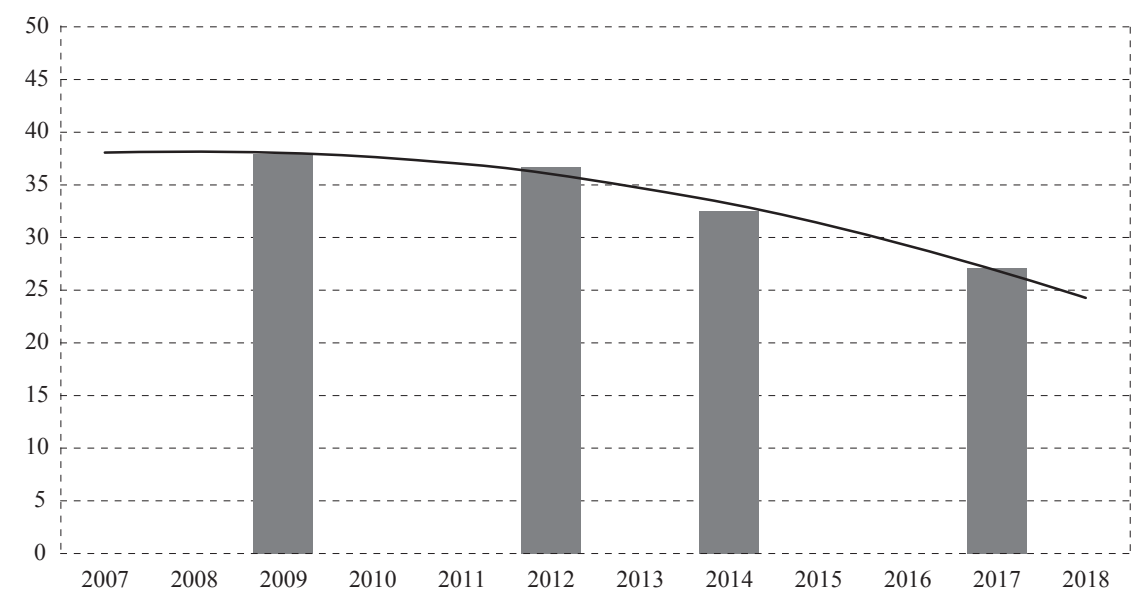

Source: ELSTAT (2009, 2014); KAPA Research (2012, 2017). 
Figure A13

Revenues from the excise taxation of tobacco products, in millions of euros
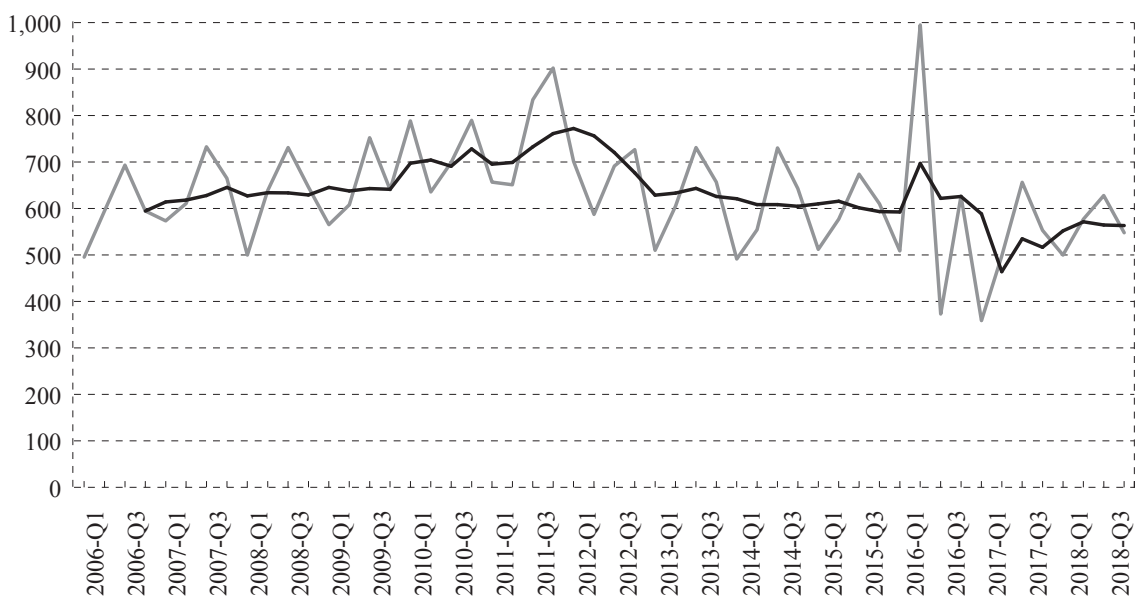

Source: ELSTAT (2019) and authors' calculations.

\section{Figure A14}

$Q_{c}$, consumed quantities of cigarettes, in billions (smoothened)

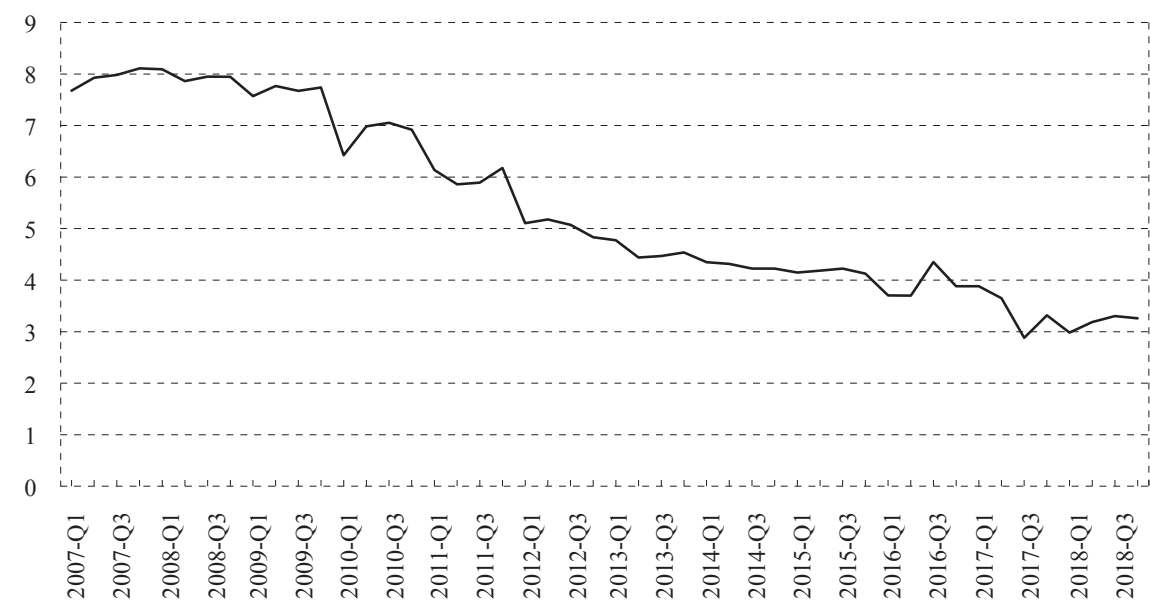

Source: KPMG (2012-2019) and authors' calculations. 


\section{Figure A15}

$Q_{\rho}$ consumed quantities of fine-cut tobacco in 1,000 tonnes (smoothed)

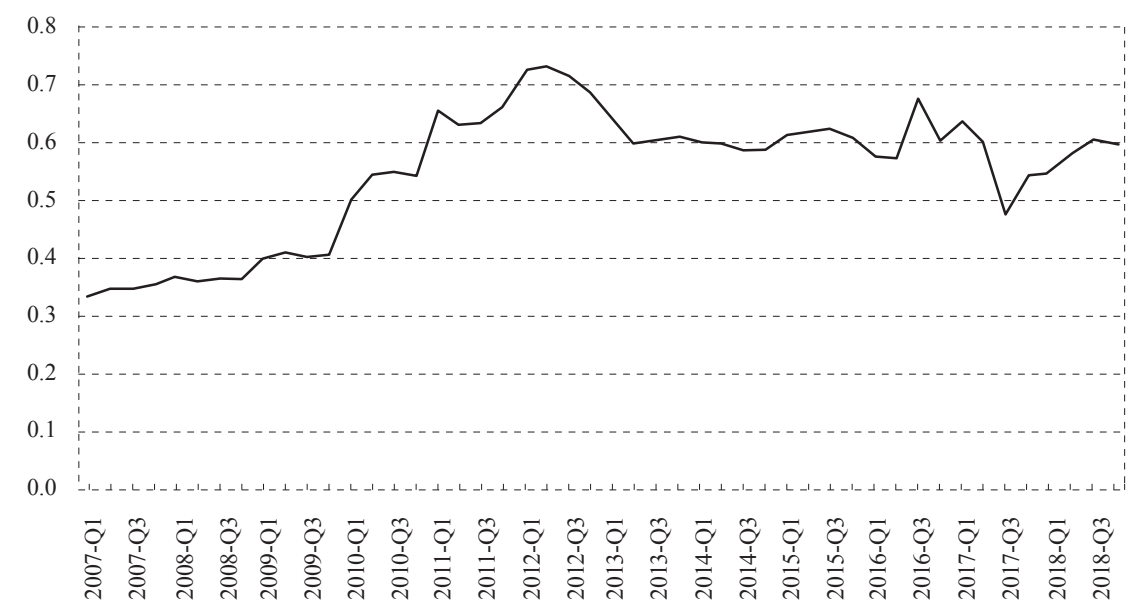

Source: Danchev et al. (2014); Maniatis and Danchev (2016); and authors' calculations.

\section{Figure A16}

Y Net National Disposable Income (NNDI), actual and smoothed (millions of $€$ )

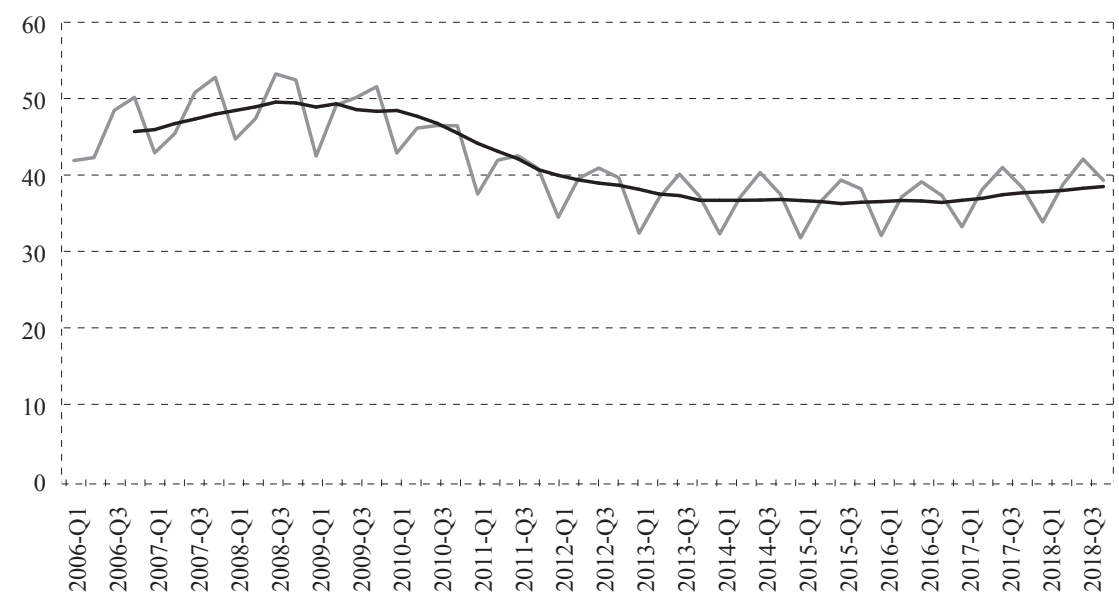

Source: ELSTAT (2019) and authors' calculations. 

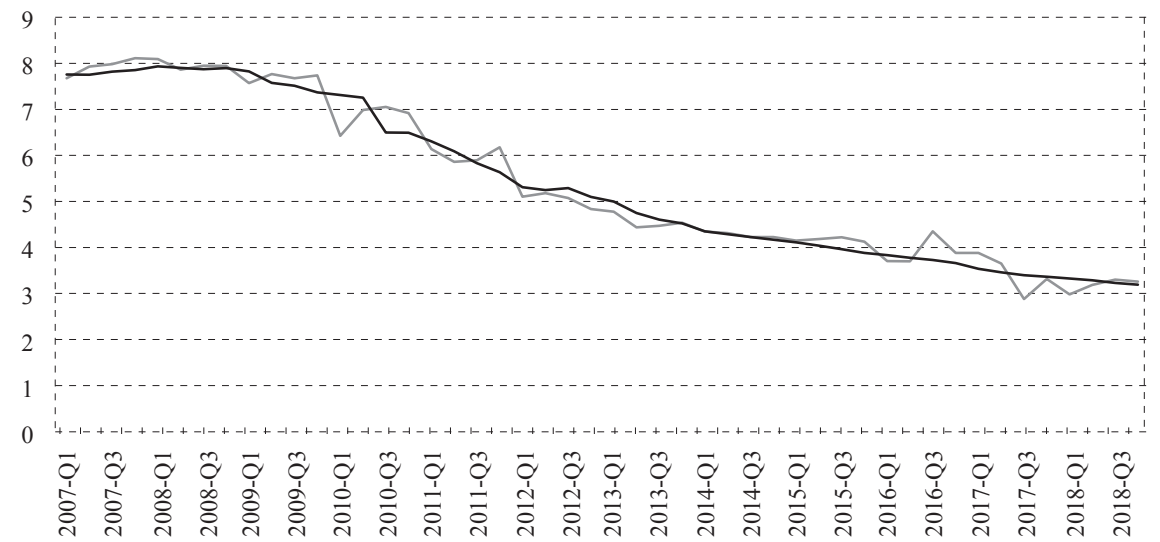

Q Q cigarettes actual (billion pieces) Sm — Q cigarettes calculated (billion pieces)

Source: Authors' calculations.

\section{Figure A18}

Consumption of fine-cut tobacco actual and calculated in 1,000 tonnes

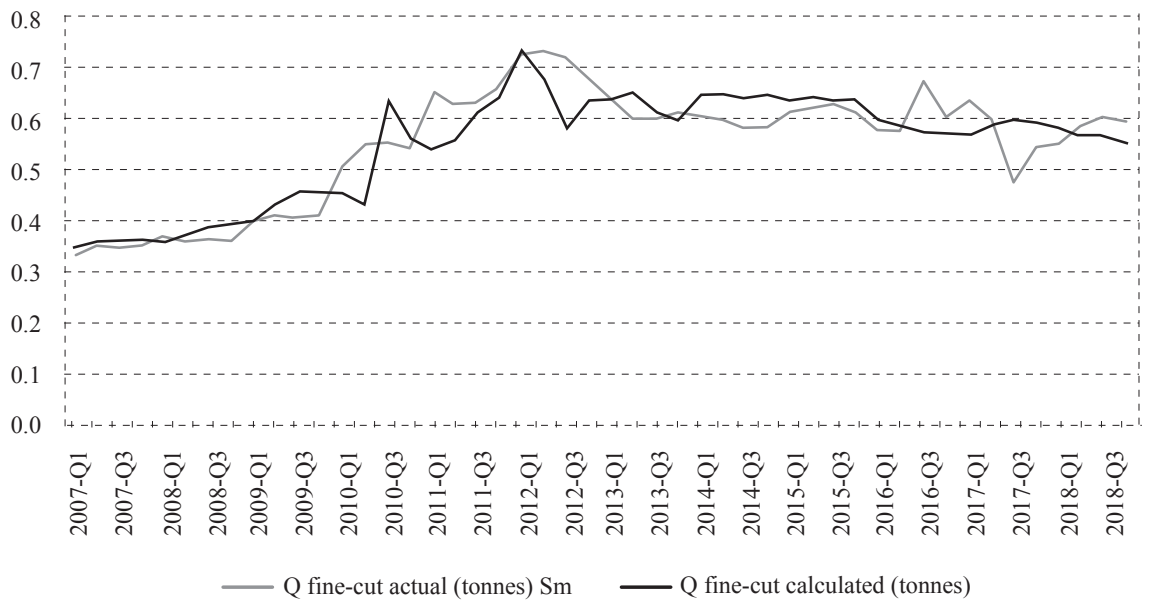

Source: Authors' calculations. 